\title{
MODERN DESIGN AND CONSTRUCTION OF DAMS AND DIKES BUILT WITH THE USE OF ASPHALT
}

\author{
BARON U.F. VAN ASBECK, M.I.C.E. \\ SHELI INTERNATIONAI PETROLEUR: CO., ITD., \\ LONDON.
}

\section{SULAGARY}

In rocont yoars quito a numbor of important coast protection and harbour construction works in thropo, in tho U.j.A. and in Japan lave been built or strengithoned with the use of asphalt according to ostablished nethods of construttion in various countries. These works have proved to be not only technically sound and durable but also conomeal in initial capital irvostnont as well as in vaintonence costs. Wioreovor, as the rosults obtainod have been very encouraging, new outlets and netlods of construction with asphalt are being sought, and systonatically invostugntod end developed to covur a wider field of arplication for coast protection and harbour construction works.

Although there aro Lany purposes and necns of applying asphalt constructions for those works, the author has linited the scope of his paper to describo in particular tho fundanental problens related to the hydraulic and asphalt-technical aspects of buildins dals and dikes of sand according to the hydraulic fill process, covered and protected by a two course hot-nix asphalt revetrient or layer.

Assuring a general knowleclee of the varzous facots of hydraulic dan and dike constructions and of asphalt construction nothods the author deals with essential itens conocrning the hydrulic and strongtl design of asphalt revetuents for dikes and dams and describes certain dotails of construction that recuure particular attention and perhaps further investigation as experionce has proved.

\section{INGTRODUCTION。}

In uany countries it is esser.tial that certain coastal stretches are protected afainst the danaging effect of waves caused by heavy storis, burricanes, typhoonos, etc. Generilly these coastal sections are limited to those parts of the country, whero the population is concentrated in towns and villaces and whero land is more valuable than in othor parts, eithor because it is well suited for industrial developrent or better suited for agricultural purposes. In an increasing nuriber of countries reclanation works are being undertaken in order to develop erployment and food production. The types of coast that require artificial protection are generilly situatcd at a low level, sonewhat lower than nomal high weter level of the sea, whilst the beach and in sone cases the dune fortation, will consist of 


\section{COASTAL ENGINEERING}

sand that may range in size from very fine sand of limited grading to coarse sand mixed with gravel of various sizes.

In this century of enormous technical progress, means have been sought to inprove the cethods of protection of these coasts and at the same tipe to reduce the cost of construction by designing dams and dikes of sound technical quality from local aggregate materials. The modern method of construction which aims at high productivity and low cost consists of building a sand core covered with and protected by an asphalt construction which is genorally laid in two courses.

Since new pethods of dike and dam construction can only be investigated and tosted to a certain extont, even if experiments in a hydraulic laboratory can assist in determining the importanoo of various factors, many itens of performance can only be judged and appreciated in actual practice. A high degree of responsibility is left to the engineer concermed in the design and construction, and it is for this reason that progress in the application of asphalt revetments has taken place in consecutive stages for various types of dams and dikes.

The first asphalt revetment was constructed on a harbour dam with a sand core, where damage to surrounding constmuctions and properties would be very linited in case of failure. The next step was taken when an asphalt revetment was built on a sand dam surrounding a large building pit, where damage to installations would not be irreparable but risks were greater than in the first case. Finally the last stage consisted of building dams and dikes which were designed to protect populated and valuable areas against the sea.

As it is impossible to describe all details of this asphalt development work in a paper of limited scope, the author has limited his description to those parts of the construction which are essential; firstly, for the design, both from a hydraulic and an asphalt-technical point of view; secondly, for the actual execution of the asphalt work; and finally for a satisfactory performance as based on experience geined in various countries.

\section{DESIGN}

It is assumed that a formation of fine granular aggregate of suitable bearing capacity is available, perhaps covered by a layer of silt that can and should be removed to a thickness of some $50 \mathrm{~cm}$. in order to obtain a sufficiently strong and impermeable layer underneath the dam.

In order to retain the core of the lam consisting of fine sand in proper shape, two parallel retaining walls of clay or other suitable cohesive material are designed under water on either sido of the dam to a height just above nomal high water lovel. Generally 


\section{MODERN DESIGN AND CONSTRUCTION OF DAMS AND DIKES BUILT WITH THE USE OF ASPHALT}

these walls will be dumped each to a height of $2-3 \mathrm{~m}$. and if a greater height is required the retaining walls are built up in stages as shown on the drawing. (Fig. I)

The core of sand is built up either by dumping the sand under water by means of bottom-door hopper barges or by the hydraulic fill process, by which sand and water are pumped through a pipe at the end of which the sand is deposited by sedimentation and the water flows baok into the sea. The send core is finally brought into shape according to the dosign by means of drag lines, bulldozers and other conventional types of earth moving equipment, and compacted if necessary.

The design of the facing of the core of the dam consists of various parts, each of which has to fulfil a specific function. The foot of the dam, from low water level downwards, has to be protected age.unst the erosive forces of currents and waves, and should consint of a flexible material, which permits the lower edge of the protective layer to follow linited deformations caused by erosion at the fbot of the construction. For this purpose brushwood mattresses or nattresses of reeds, loaded with stone, have proved to be effective and durable. Some experimental stretches have been carried out with reinforced. asphalt constructions, which have proved successful if constructed in situ in a continuous layer; but prefabricated reinforced asphalt mattresses of limited dimensions have sometimes resulted in less satisfactory performance, in particular where the nattresses were not laid in sufficiently deep wator so that the waves were able to play on the nattresses, thus causing vertical displacements which in turm transformed the sand beneath into quick sand of reduced stability.

At low water level or in its proxinity a sheet piling is generally built to a dopth of some $2 \mathrm{~m}$. in ordor to prevent or reduce the direct influx of water under the dar or dike. A timbor sheot piling should remain under water practicelly percanently, but if concrete is used, the top of the shoot piling may be laid higher. This is generally of advantage for construction purposes and ney also be preferable to obtain a stronger protection at this most vulnorable point of the dam.

Thoro are two types of essenticl problens attached to the design as described above. Related to the hydraulic dosign are two inportant questions, viz. (1) what seaward slope should be given to the dan and. (2) what should be the height of the dan. There are also two questions related to the asphelt design, viz. (1) how thick should the protective revetment be laid, and (2) what is tho most suitable composition.

\section{HYDRAULIC DESIGN}

If anything has been learnod during the centuries of dike building experience, it is this: through some unexpected event that may occur any day, waves bay overtop tho dike and cause a breach unless it is 


\section{COASTAL ENGINEERING}

also properly protected over its crest and on the back slope. Events, such as a storm flood level caused by strong winds, surpassing a previous highest registered storm flood level, or a storm of longer duration than ever experienced before, may be the cause of breaches, for a clay or turfed top soil nay be soaked to such a degree, that it loses stability although it may resist the erosive action due to the flow of water. In such circunstances the protection will slide down the slope and the core will be graduajly washed away until the dike, togethor with its protective revetuent on the seaward side, collapses, thus causing the initial stage of a breach, followed by serious flooding, if no quick measures for repair are or can be taken.

Another experience to ronember is that in coast protection work It is not technically sound or economical to try to resist the forces of waves by building very heavy, rigid and steep structures. Such structures will inevitably also collapse if attached by water from the rear. Although it may be necessary to build a somewhat higher dike, It has proved to be nore effective and nore economical to build a reasonably flat seaward slope and protective revetment to meet the force of breaking waves and to guido the uprush of water along a streamlined profile rather than to rosist outright the force of the waves.

Fngineers experionced in dike design and constmuction methods all secm to agree with the preference, if not the necessity, of protecting dikes of sufficient height with artificial revetuents and of building streamlined structures.

These are fundamental conditions which govern nodern dike design in principle, but the dimensions have still to be determined to suit specific local conditions. A great deal of research and experimental work has been carried out in post war years in various hydraulic laboratories to investigate and determine the features and perfornance of various types of designs for dans and dikes. Formulas have been developed, among others, for assessing approximately the uprush of waves on a revetrient laid on slopes of varying angles. Various types of materials have also been subjected to these tests under varying conditions of exposure $(1,2,3)$.

Note: Numbers refer to literature at the end of the paper.

A formula derived by the Hydraulic Laboratory at Delft from experinents carried out in a wind flume seoms to give a practical approach for determining the vertical height of upiush of the significant wave for an open, close-set stone revetment for slopes not stecper than 1 vertical in 3.5 horizontal. 
MODERN DESIGN AND CONSTRUCTION OF DAMS

AND DIKES BUILT WITH THE USE OF ASPHALT

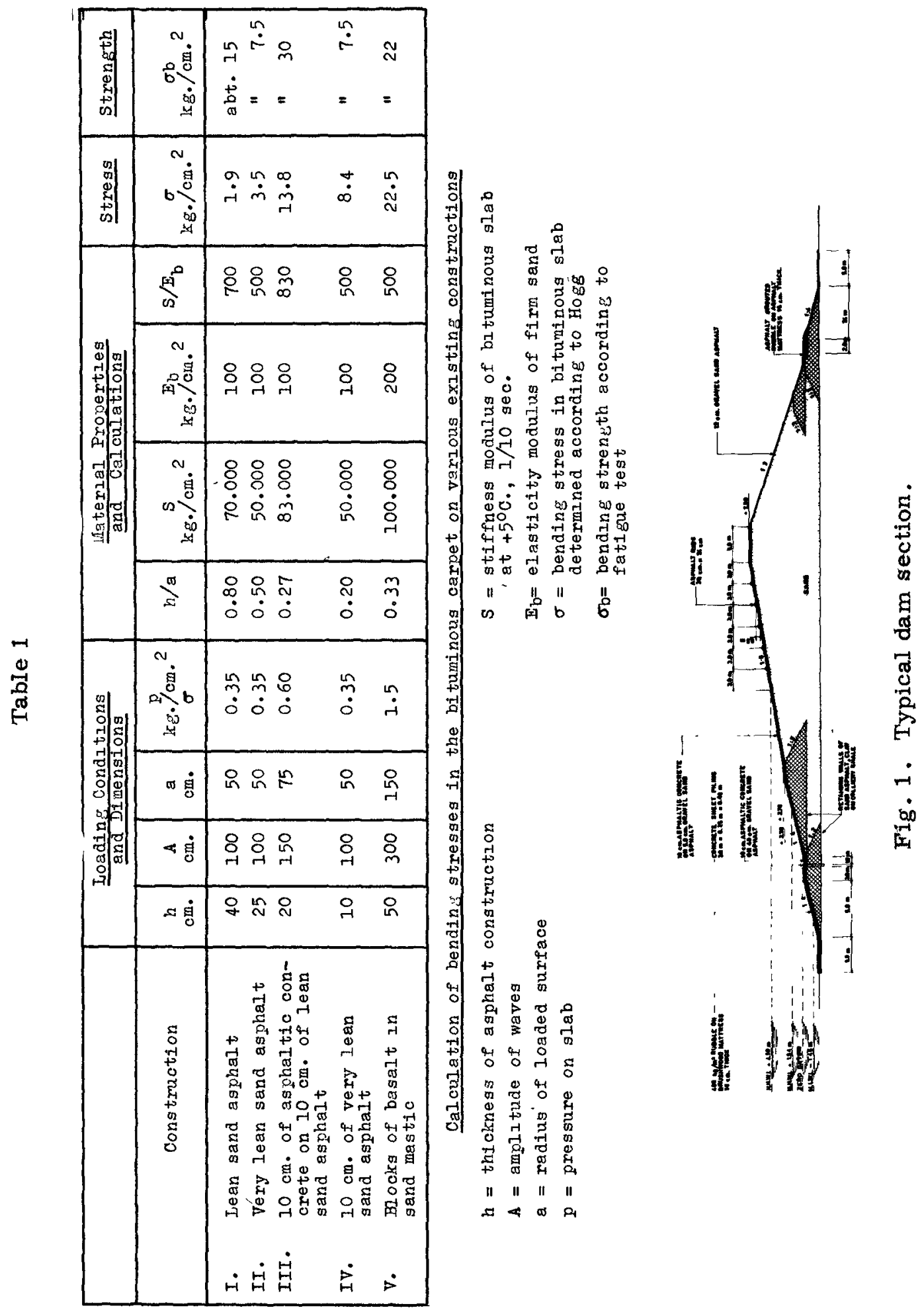




\section{COASTAL ENGINEERING}

$$
Z=8 H\left(\cos 1-\frac{B}{L}\right) \tan \cdot a
$$

in which $\mathrm{Z}=$ height of uprush of waves, measured vertically above storm flood level, adnitting $2 \%$ of over-topping waves.

H = significant wave height or average anplitude of the highest third part of all recorded waves.

$i=$ angle 'of incidence of the waves.

$B=$ width of berm

$\mathrm{L}=$ wave length

$a=$ angle of the slope.

Fomerly the height of uprush of waves was defined as the vertical height above the highest registored storm flood level, but sinco 1953 a calculatod storm flood level has been introduced in Holland, which is based on a combination of extreme meteorological weather conditions. Such a calculation requires, however, a great number of data and a detailed knowledge of the prevailing conditions on the coast.

A smooth, impervious surface increases tho uprush by $15 \%$.

Slopes may vary from $1: 3$ to $1: 10$ according to their expis:.se to winds and waves; for an average $1: 6$ slope the uprush of a wave of $3 \mathrm{~m}$. amplitude on an asphaltic concrete construction would be approximately $4.60 \mathrm{~m}$., measured vertically.

Recently a new method of reducing the uprush of waves has been designed and investigated by the Delft Hydraulic Laboratory (4). It consists of applying a range of 4 to 5 asphaltic concrete ribs, built at $0.50 \mathrm{~m}$. intervals, measured vertically, with the botton rib equally constructed at $0.50 \mathrm{~m}$. height above the maximum registered storm flood level, as shown on the drawing. The purpose of this range of ribs has been demonstrated experimentally in actual practice and has shown that the uprush of a thin layer of water which has lost the majority of its energy can be effectively reduced by $50 \%$.

The ribs are built to a section of $30 \times 30 \mathrm{~cm}$. in lengths of $4 \mathrm{~m}$. with intermediate open spaces of $0.80 \mathrm{~m}$. length to allow the water to recede more freely and form a layer of resistance to the following oncoming wave.

Incidentally it should be borne in mind that on a seaward slope of any type of protective material the uprush of waves during storms 


\section{MODERN DESIGN AND CONSTRUICTION OF DAMS AND DIKES BUILT WITH THE USE OF ASPHALT}

only takes place from storm flood lovel upwards along the slope; the strongest wave attack with the groatest impaot and uplift is to be found between mean high wator lovel and storm flood level, whilst the revetment is only subjected to moderate, but on the other hand perpetual, wave attack with erosive action below mean high water level.

\section{ASPHALT DESIGN}

The systenatic use of asphalt for dams, and later for dikes, dates from the early post-war period, when it was suggested to budid a harbour dam of a sand core protected by an asphalt facing as the most econorical solution for tho reconstruction of the entrance to the port of Herlingen in Holland. (1). The economical construction was based on the fact, that use could be made of local fine sand that was available in abundanco in the seas, whereas other construction materials would have had to be brought to the site from long distances. At that time considerable knowledge was available of the fundanontal principles of the construction of asphalt roads, but little was known about the application of asphalt to dams, apart from the fact that asphalt constructions wore cohesive to the oxtent of boing ablo to resist the forces of erosive action of small waves, that asphalt constructions could be made impervious if properly designed according to fairly strict specifications, and that asphalt layers were sufficiently floxible to bo ablo to follow limitod deformations such as could be expected on dams subjected to normal settloment after construction. However, there was only one type of sand availablo at Harlingen and littlo was known not only about the requirod strength of the revetment but also of the strength of the asphalt material on which the determination of the thicknoss of the revetment wculd depend. It was, therefore, deciled to build a short trial length on the site of the dam and as its performance was good during the following winter, the whole dan was built in its entrre length during the next year and protected with the tested type of revetront, consisting of a single layer of sand asphalt, $40 \mathrm{~cm}$. thick, betweon mean low water level and maximum high wator level on tho soaward slope, and $25 \mathrm{~cm}$. thick on the remaining seaward slope, the crest and the harbour sido of the dam. After consolidation of the sand asphelt revetment the whole surface was imnediatoly covered with a seal coat of pure bitumen and finally finished with a thin surface dressine, including a rolled layer of sea shells to obtain a light colour of the surface. The result was good and the perfomance of the dam during the following yoars was satisfactory, but it was considered that the qualities of the asphalt layer could be improved. Consoquently, work was started in laboratorles and in actual practico to investigate all possible means of improving the quality of the asphalt materral and of obtaining a bettor understanding of all factors involved in this matter. 


\section{COASTAL ENGINEERING}

This systematic development was based on the extension of existing research work related to other types of hydraulic problens covering the construction of large dans, reservoirs, river bank protoction etc., carried out in various laboratories and also on improved nethods of actual asphalt construction, either by means of manual labour or with mechnical equipment.

The scope of this paper does not permit a full description of the more scientific background of the asphalt techniques related to this problem, but a sumarised description is given with reference to existing literature on the subject, which will show the student of this natter the way to a wore fundamental study.

As is gonerally known, bitumen is a solid at low temperatures but on heating it is gradually transformed into a fluid state, . whilst on cooling the reverse process takes place; expressed in more scientific terms, bitunen can be considered as a visco-olastic material.

In applied nechanics the characteristics of a purely elastic solid are defined by its modulus of elasticity, or Younc's nodulus, which indicates the linerr relationship betweon stress and strain. But for a visco-elastic material this linear relationship is dependent on (a) the tine of loading (for static loading conditions) or the frequency of loading (for dynamic loading conditions) and ( $b$ ) the temperature. The influence of the terperature, or in other words the temperature susceptibility of a bitunen, is expressed by the "Penetration Index" or P.I. of the bitumen. By neans of the inter-relationship between the loading, or frequency of loading, the ambient temperature and the P.I. of a bitunen, it has been possible to conpose a nomograph from which the "stiffness nodulus" of a bitumen (the equivalent value to the nodulus of elasticity of a solid) can be determined under specific conlitions of environment (5).

For design purposes of an asphalt hydraulic construction the engineer is, howevor, nore concomed with the properties of a hot-mix asphalt construction consisting of mineral aggregates, filler and bitunen rather than with the performance of a pure bitumen. The relationship between the stiffness modulus of a hot-mix asphalt composition and that of a pure bitumen has been found to depend mainly on the concentration by volume of ninoral aggregates in the asphalt mix. The stiffness nodulus of various asphelt bixes has been detormined.

It has also been possible to determine tensile, compressive ant bending strengths of asphalt mixes by neans of laboratory tests and here again the properties of the mix, depend, of course, on duration of loadine and temperature (6). 


\section{MODERN DESIGN AND CONSTRUCTION OF DAMS AND DIKES BUILT WITH THE USE OF ASPHALT}

Finally it has been found by fatigue tests that if the cycle of loading is repeatod on asphalt mixes, the number of loadings to failure increases as the stresses decrease. The relationship between the number of repetitions of loading and the bending strength at fatigue rupture has been detormined (6).

For the calculation of the dimonsions of an asphalt facing on a dam subjected to dynamic forces by waves, reference can be made to a graphical method of determining bending stresses and corresponding deflections in hot-mix asphalt constructions. This mothod was devised by Odemark and Hogg and is based on the assumption that an asphalt revetment is virtually a flexible construction laid on and completely supported by a homogeneous, flexible sub-soil and is loaded repeatedly by a given pressure on a circular area. (7).

For the application of these graphs, it is therefore necessary to base the calculation on assumptions for the characteristics of the breaking waves. The properties of the asphalt layer, i.c. its modulus of stiffness and its designed thickness, as well as the modulas of elasticity of the sub-soil, should also be known.

Tho forces exerted by waves depend on a combination of factors, some of which are difficult to assess but can be found in existing literature. It scems reasonable to assume, that the striking area of a vave covers a surface, the diameter of vihich equals tho amplitude of tho wavo, wheroas the duration of its impact can be taken at $1 / 5$ or $1 / 10$ of a sccond. Assuming further a tomperature of about $56 \mathrm{C}$, the modulus of stiffness of a hot-mix asphalt revotment will be of the order of $5 \times 104 \mathrm{~kg} . / \mathrm{sq} . \mathrm{cm}$. If the asphalt revetment is laid on newly compactcd sand, its modulus of elasticity can be takon at $100 \mathrm{~kg} . / \mathrm{sq} . \mathrm{cm}$.

Comparison of the bending stress, calculated as described above, with the bonding strength of the hot-mix asphalt layer under repeated loading conditions will give an indication of the safoty margin adopted for tho design.

In connection with the stability of the core of fine sand supporting the asphalt facing the deflection of tho asphalt layer should be limitud to $1 \mathrm{~mm}$. In which case a moist sand core will still retain its stability.

Although generally spoaking, there need not be any fear as regards the creep of a properly designed hot-mix asphalt revetment on a comparatively flat slope under noderate atmospheric tempertures, it may be desirable to consider the plastic properties of the asphalt mix under somewhat more severe conditions that way, for instance, isrevail in sub-tropical or tropical 


\section{COASTAL ENGINEERING}

countries. Under such conditions the methods of determining the characteristics of the asphalt mix can be compared with those appliod in modarn soil mechanics techniques for determining the properties of a soil in which, however, the soil/water system is replaced by an aggregate/bitumen system (6). By means of tho triaxial tost figures oan be determined for:

(a) The angle of internal friction,

(b) The initial resistance, consisting partly of the true interlooking rosistance of the aggregate particles

and (c) The viscosity of the mass.

These propertios of bituminous mixes are again partly depondent on their temperature. For given conditions of an asphalt facing on a slope of a dam it will be possible to determine tho degree of stability if the intermal friction and the initial resistence are known, besides of course, the thickness and the specific gravity of the asphalt rovotment. In order to obtain equilibrium of the asphalt facing on a slope it is "necessary that the difference between the shear stress due to the weight of the asphalt facing and the shear resistance due to its intermal friction is at least balanced by the initial resistance of the asphalt naterial.

As an interesting example of the calculation of bending stresses in asphalt revetmonts on various constructions in Holland the following table indicates some essential figures required for this calculation. The table also shows the comparison between the calculated bending stresses in the asphalt facings and the actual bonding strengths of the various types of asphalt compounds, as determined by fatigue tests (7). See Table 1.

The bending strengths were based on a storm lasting 36 hours during which the impact of waves was repeated about $1.1 \times 104$ times. It will be seen that there is good correlation betwoen the calculations and the results in actual practice, since, after the storm, constructions I, II and III wore undanaged, construction IV was of an underdesigned vory lean sand asphalt and was heavily danaged, whilst construction $V$ showed cracks as the critical value of the bending stress for a sand mastic was reached.

From various data on the determination of bending stresses it would soen that the following maximum bending strengths of the various asphalt materials can be adapted:

$\begin{array}{ll}\text { Asphaltic concrete } & 30 \mathrm{~kg} . / \mathrm{sq} . \mathrm{cm} . \\ \text { Lean sand asphalt } & 15 \mathrm{"} " \\ \text { Very lean sand asplalt } & 7.5 \mathrm{ll} "\end{array}$




\section{MODERN DESIGN AND CONSTRUCTION OF DAMS AND DIKES BUILT WITH THE USE OF ASPHALT}

. In another case the deflections of asphalt revetments have been calculated according to the above nentioned methods and the following results wero found:

\begin{tabular}{|c|c|c|c|c|c|c|c|c|}
\hline $\begin{array}{l}\text { Thickness } \\
\text { constructi }\end{array}$ & & A & $\begin{array}{l}\mathrm{a} \\
\mathrm{cm}\end{array}$ & $\frac{\mathrm{p}}{\mathrm{kg} / \mathrm{or}^{2}}$ & $\mathrm{~h} / \mathrm{a}$ & $\stackrel{\mathrm{S}}{\mathrm{kg} / \mathrm{cm}^{2}}$ & $\underset{\mathrm{kg} / \mathrm{cm}^{2}}{\mathrm{E}}$ & $\underset{\mathrm{mm}}{\text { Deflection }}$ \\
\hline North side & $\begin{array}{l}25 \mathrm{~cm} \\
35 \mathrm{ct}\end{array}$ & 75 & 37.5 & 0.25 & $\begin{array}{l}0.57 \\
0.94\end{array}$ & $\begin{array}{l}70,000 \\
80,000\end{array}$ & 100 & $\begin{array}{l}0.267 \\
0.169\end{array}$ \\
\hline South side & $\begin{array}{l}25 \mathrm{~cm} \\
35 \mathrm{~cm}\end{array}$ & 50 & 25 & 0.15 & $\begin{array}{l}1.0 \\
1.4\end{array}$ & $\begin{array}{l}70,000 \\
80,000\end{array}$ & $"$ & $\begin{array}{l}0.070 \\
0.048\end{array}$ \\
\hline
\end{tabular}

In certain instances there nay be a possibility of hydrostatic pressure developing underneath the asphalt facing where the height of saturation of the sand core of the dam by water due to prolonged high sea water levels, is not linited sufficiently by noans of drainage. The equilibriun of the asphalt revetment is a sinple matter of constructional design and is only referred to as an essontial matter of clesign that can be solved oither by providing adequate drainago or by providing sufficient weight and thickness to the covering asplalt layer.

If a dan or a dikc is completcly capped by an inporvious asphalt construction, air pressure may develop in the core of the structure owing to a slight rise of tho water level in the core. Since tho asphalt covor is a plastic layor, it will be deformed by this pressure unloss air vents are applied at intervals of $25 \mathrm{~m}$. in the form of short steel pipos filled win procoatod chippings.

\section{ASPHALT CONSTRUCTION ( 1 )}

In asphalt dam construction work it has always boon found essontial to construet a top course as a dense inpervious asphaltic concrete layer, whilst in recont years it has also becn the ain of the designers to specify a dense base course instead of the more open graded send asphalt mix which was originally laid. The improvement in technical quality is important as compared with the slight increase in cost of the total construction. In order to obtain the required density and inpermeability of the two courses it is neoessary to specify a figure for the density or else to specify limits for the void contont in the compactod nixes. The present figures for void contents are 2 - $4 \%$ for the top course and a maximum of $10 \%$ for the base course. 


\section{COASTAL ENGINEERING}

Apart from the degreo of compaction, the possibility of achieving tho required density depends naturally on the composition of the mix, determined by the grading of the ageregate material and filler, whilst the amount of bitumen is determined by tho quantity required to fill the voids in the corpacted dry mix of aggregates and filler. An average type of composition for the two asphalt coursos consists at prescnt of:

Top Course: (Asphaltic concrete)

Base Course: Gravel sand asphalt)
$42 \%$ crushod stone, $3-12 \mathrm{~mm}$.

43\% gradod sand finer than $2 \mathrm{~mm}$.

$7 \%$ linestone filler

$8 \%$ biturien $80 / 100$

43\% gravel, $5-20 \mathrm{~mm}$.

$43 \%$ graded sand finer than $2 \mathrm{~mm}$.

$7 \%$ limestone filler

$7 \%$ bitumen

For asphalt mattresses or asphalt grouting work the sand mastic consists of approximately $75 \%$ sand, $10 \%$ limestone filler and $15 \%$ bitumen $80 / 100$.

The reinforcement of asphalt nattresses can consist either of sisal nets of $10 \mathrm{~cm}$. mesh and $6 \mathrm{~mm}$. cord diameter or of flexible steel fabric of $10 \mathrm{~cm}$. mesh and $2 \mathrm{~mm}$. wire diameter.

An experimental avorago composition for asphalt ribs to reduce the uprush of waves consisted of:

$$
\begin{aligned}
& 43.8 \% \text { crushed stono, } 5-12 \mathrm{~mm} \text {. } \\
& 41.7 \% \text { graded sand } \\
& 8.1 \% \text { limestone fillor } \\
& 6.4 \% \text { bitumen } 80 / 100
\end{aligned}
$$

The asphalt ribs are applied without difficulty with a conventional typo of curb-paver as used for roadwork; it is essential to apply a tack coat of a hard grade of bitumen on the sloping asphalt facing of the dam.

As for hydraulic works of various nature, such as large dams, reservoirs, canal linings, etc., the heating and mixing procoss of mineral aggregatos, filler and bitumen is carried out in conventional types of rixing plants whilst the dix is generally transported to the site of laying by moans of lorries as is current practice in roadwork. Contrary to nomal practice in the construction of large dams of $40 \mathrm{~m}$. height and wore, as woll as for the construction of reservoirs and hoad races leading to hydro-eloctric plants, where laying of the asphalt linings is generally carried out by means of mechanical equipuent, such as road finishers or specially constructed spreador-boxos, it is the usual practice to lay asphalt facings on dans and dikes for coast 


\section{MODERN DESIGN AND CONSTRUCTION OF DAMS AND DIKES BUILT WITH THE USE OF ASPHALT}

protection by manual labour. The reasons for this fact are twofold: firstly, the surface on which the base oourse of the asphalt facing is laid genorally consists of sand that is, even after compaction, not sufficiontly stable to support the weight of moderm laying equipnent and, seoondly, the thickness to which the base course is laid varies from at least $20 \mathrm{~cm}$. to $60 \mathrm{~cm}$. or more at the foot of certain dams so the advantage of mochanical laying is reduced since not much hand labour is required to spread the material. The top course of dense, impervious asphaltic concrete is laid on a good, stable support to an average thickness of $10 \mathrm{~cm}$. maximum and here, of course, there should be every reason for laying and rolling the surface with moderm road surfacing equipment adapted to work on fairly flat slopes. So far little use has, however, been made of mechanical equipment and the quality of the work would certainly be inproved, if hand labour were roplaced by machinery.

Compaction of a thick base course is generally achieved by hand tampin; on a thick plank, where no other means of compaction could be more effective in reducing the percentage of voids in the finished asphalt layer. If the base course consists of better graded agrregates, goou reason exists to apply a more effective method of compaction either by means of light vibrating singlewheel steel rollors, light motor rollers or by vibrating tampers. In the latter case compaction sheuld continue till no more tracks are seen on the asphalt surface.

It is necessary to obtain a good bond between the two asphalt courses and this can best be achieved by applying a tack coat of about $0.75 \mathrm{~kg} . / \mathrm{sq} . \mathrm{m}$. of a hard grade of bitumen while the asphalt base courge is still warm. Before layng the top course the asphalt surface should be thoroughly oleaned in order to obtain good adhesion.

It is generally specified, that the joints between the asphalt areas finished at the end of a day and new work should be laid staggered in the two asphalt courses. Moreover, it is also normally specified that the joints should be painted with bitumen before the adjacent asphelt area is laid.

A seal coat of approximately $2 \mathrm{~kg} . / \mathrm{sq} . \mathrm{m}$. of a soft grade of bitumen should be applied whlle the asphaltic concrete top course is still warm and in any caso before it has been covered by water. Because aıgae do not adhere to pure bitunen; only the asphalt surface above normal high water level is covered with a very thin layer of heated gravel, sand or sea shells and compacted. 


\section{COASTAL ENGINEERING}

\section{EXPERIENCE AND RBCOMMENDAPIONS}

During the post-war years much experience has been gained on the construction of asphalt works for hydraulic purposes of various types and in nany countries, and in connection with the application of asphalt faoings to dans and dikes, it would seem of value to review the various essential items of construction and to summarise recormendations for future work.

\section{(1) CORE OF THE DAM}

There are certain advantages and disadvantages in buildine parallel retaining walls of clay, both from a constructional point of view as well as in rolation to their function in the permanent structure. It harly need be emphasised that the clay used for this purpose must retain its stability under water and be easy to apply; rich clay is therefore unsuitable, the more so bocause it has a tendency to crack when drying out. It is, thorefore, prudent to specify that the clay should be of suitable quality containing not loss than $30 \%$ fine sand.

Tho clay should also be able to resist temporary erosion by waves and currents until it is protected by the facing of the dar. It should be sufficiently cohesive to protect the sides of the sand core to a certain extont during tho storms and on the other hand it should not be too rich as this will cause undue differences in the degree of settlement between the retaining walls and the sand of the core.

The surface of the clay retaining walls hes gonerally to be partly covered by the asphalt facing and its rough surface will tond to increase the quantity of asphalt material necessary for the bese course. Attention should be drawn to the fact that, especially if the hydraulic fill process is applied for the construction of the dan, drainage of water contained in the sand core is prevented by the clay retaining walls. For these reasons, and also because the required quantities of clay may not always be available, it is interostine to noto that a sand asphalt containing not nore than $3 \%$ bitumen can be used for this purpose. This lean sand asphalt mix oan bo dumped under water by neans of bottom-door hopper barges, and it has boen proved that it can resist a certain degreo of water turbulence and current velocities up to at least $3 \mathrm{~m}$. per second. In the last few years the use of colliery shale instead of clay has given satisfaction for the construction of those rotaining walls. 


\section{MODERN DESIGN AND CONSTRUUCTION OF DAMS AND DIKES BUILT WITH THE USE OF ASPHALT}

(2) CONSTRUCTION OF THE FOOT

(a) If the foot of the dam bolow normal low water level is protected by a permeable type of construction, such as fascine mattresses, it is essential to apply a sheet piling to resist percolation of water through the sand formation. In certain circumstances it nay be of advantage to lay a continuous drain or weep holes behind the sheet piling and in order to reduce the pressure afainst this sheet piling, it is desirable to provide a berm of $1 \mathrm{~m}$. width between the sheet piling and the foot of the sloping facing.

(b) If, on the other hand, the foot of the dam below norral low water level is protocted by an imporvious and flexible reinforced sand mastic layer, it is good practice to lay the asphalt mattress against the sheet piling and to covar both with asphalt grouted rubble against which the sloping asphalt facing is laid.

\section{(3) AIRVENTS}

Airvents at intervals of $25 \mathrm{~m}$. should be constructed in the crest of an asphelt capped dan or dike in the form of short steel pipes filled with precoated chippings if air pressure can be expectod to devel op undermeath the asphalt cap.

\section{(4) ASPHAIT RIBS}

Care should be taken that the composition of the asphalt ribs is based primarily on stability design and that a tack coat of a hard grade of bitumen is applied to obtain good adhesion of the ribs to tho sloping asphalt facing of the dan.

\section{(5) ASPHALT JOINTS}

(a) It is desirable not to lay any horizontal asphalt joints under normal high water level or even better under the highest high water level.

(b) Asphalt joints in the two courses should be laid staggered.

(c) The cold surfaces of asphalt joints should be cut obliquely and coated with a thin leyer of sand mastic before finishing the day's work; these surfaces should be thoroughly cleaned before the adjacent asphalt areas are laid.

(d) Under these conditions there is no need to increase the thickness of the asphalt facing at the joints as this only complicates the construction without increasing the strength or impermeability. 


\section{COASTAL ENGINEERING}

\section{(6) TACK COAT}

It is essential to apply a tack coat of $0.75 \mathrm{~kg} . / \mathrm{sq} . \mathrm{m}$. of a hard grade of bitumen on the baso course while it is still warm; the asphalt surface should bo thoroughly cleaned before applying the top course.

\section{(7) SEAL COAT}

Before the asphalt surface has cooled off and at any rate before it has been covered by water, the whole surface of the asphaltic concrete top courso should be sealed by applying $2 \mathrm{~kg} . / \mathrm{sq} . \mathrm{m}$. of a soft grade of bitumen. In order to prevent the growth and adhesion of algae, which tend to cause cracks and curling up of this seal coat, the lattor is not covered below normal high water mark. Above this level the seal coat is covered oither with heated chippings, gravel sand or soa shells compacted by rolling, in order to render a light coloured surface. It should be mentioned that in several instances of construction of asphalt facings on large dams and reservoirs, it has been observed that a treatment of the asphalt surface with a cenent wash, containing equal parts by weight of cenent and wator, at a rate of $2 \mathrm{~kg} . / \mathrm{sq} . \mathrm{m}$. was effectivo in preventing cracks in a bituninous seal coat caused by expansion and contraction idue to repeated wetting and drying of clay, silt or algae, which tend to cover the asphalt surface.

\section{(8) COMPACTION}

The method of compaction of the asphalt courses need not be specified, but it is essential that the courses possess the required density and iupermeability; this can be achievod by spocifying a void content for tho asphaltic concrete top course of $2-4 \%$ and for the dense base course of a maximum of $10 \%$ by volume.

\section{(9) CONTROL OF WORK}

The quality of the asphalt construction should be controlled on the site in order to be able to adjust specifications or items of construction within a short period. Regular sieve analyses should be made of now supplies of mineral aggregates and filler, and the softoning point and penetration of bitumon should be deteminod. Means should be available of detormining the corposition of the asphalt nixes, whilst tho percentage of bitumen should be adjusted to fill the voids in the compacted dry mix of aggregate.

Regular control of the finished asphalt courses should also be arranged either by detoruining thoir density and inperweability in situ or else by taking samples and determining their donsity and impermeability in the field laboratory. 


\section{MODERN DESIGN AND CONSTRUCTION OF DAMS AND DIKES BUILT WITH THE USE OF ASPHALT}

\section{REFERENCES}

(1) "Bitumen in Hydraulic Ingineering" Volume I, by Baron W.F. van Asbeck, M.I.C.E. - Published by Shell Intemational Petroleum Company Linited, London, 1959.

(2) Modol Investigation on wave mun-up carricd out in the Netherlands during the past twenty years" by F. Wassing Proceedings of Sixth Conferoncc on Coastal Engineering, 1957.

(3) "Uber den Wellenauflauf' bei Asphaltdeckwerken" by Ref.Beuassessor F.F. LItscher - Bitumen, No. 3, April, 1954.

(4) "Remmende invloed op golfoploop door ribbels op gesloten dijkbekleding" J:C. Jelgerhuis Swildons - De Ingenieur, No. 29, 1957.

(5) "A General System doscribing the Visco-Elastic Properties of Biturnens and its Relation to Routine Test Data" by $C$ van dor Poel - Journal of Applied Chemistry, Volume 4, Part 5, May, 1954 and publishod as Sholl Bitumen Reprint No. 9.

(6) "Sone Observations on the Propertios of Bitumen/Mineral aggregate Mixtures in Rolation to their Application in Hydraulic Works" by Dr. L.W. Nijboer - Translated fron "De Ingenieur" No. 29, 1952 and published as Shell Bitumen Reprint No. 8.

(7) "Sone Considerations in designing Bitumınous Dike Revetments" by Dr. L.W. Nijboer - Trenslatud from "De Ingenieur" No. 52, 1954 and published by the Royal Dutch/Shell Laboratory at Ansterdan. 